\title{
POTENSI VITAMIN C UNTUK MENCEGAH PENYAKIT PARU OBSTRUKTIF KRONIK
}

\author{
Devista Beki Srianuris \\ Fakultas Kedokteran, Universitas Lampung, Jl. Prof. DR. Ir. Sumatri Brojonegoro No.1, Gedong Meneng, \\ Kec. Rajabasa, Kota Bandar Lampung, Lampung, Indonesia 35145 \\ devistabekisrianuris99@gmail.com (+6282213197181)
}

\begin{abstract}
ABSTRAK
Penyakit Paru Obstruktif Kronik (PPOK) adalah penyakit yang umum terjadi, dapat dicegah, dan dapat diobati yang ditandai dengan gejala pernapasan persisten dan keterbatasan aliran udara karena abnormalitas saluran udara atau alveolar yang biasanya disebabkan oleh paparan gas atau partikel berbahaya dan dipengaruhi oleh faktor penderita misalnya perkembangan paru yang abnormal. Sehingga diperlukan cara untuk mencegah PPOK, salah satunya adalah dengan pemantauan nutrisi berupa pemberian vitamin $\mathrm{C}$. Tujuan ini bertujuan untuk mengetahui potensi vitamin C dalam pencegahan PPOK. Metode tinjauan literatur ini disusun menggunakan data sekunder berupa sumber yang diperoleh berdasarkan daftar pustaka yang tertera. Sumber pustaka yang digunakan yaitu berasal dari jurnal berupa artikel penelitian, guideline, ataupun buku elektronik seperti dari NCBI, Elsevier, WHO, dan jurnal kesehatan lainnya. Metode analisis yang digunakan adalah systematic literature review dengan cara mengidentifikasi, mengkaji, mengevaluasi, serta mengembangkan secara sistematis penelitian yang sudah ada dengan fokus topik tertentu yang sesuai. Hasil analisis dari sumber pustaka menunjukan bahwa vitamin $\mathrm{C}$ memiliki potensi untuk menghasilkan efek positif pada tubuh pasien PPOK.
\end{abstract}

Kata kunci: Pencegahan; PPOK vitamin c

\section{THE POTENTIAL OF VITAMIN C TO PREVENT CHRONIC OBSTRUCTIVE DISEASE}

\begin{abstract}
Chronic Obstructive Pulmonary Disease (COPD) is a common, preventable and treatable disease that is characterized by persistent respiratory symptoms and airflow limitation that is due to airway and/or alveolar abnormalities usually caused by significant exposure to noxious particles or gases and influenced by host factors including abnormal lung development. Therefore, we have to find the prevention of COPD by monitoring potential of vitamin $C$. The purpose of this article is to determine the potential of vitamin $C$ to prevent COPD. The method used is a literature review. This literarute review was made from secondary data in the bibliography. The sources used are journals, guidelines, or electronic books from NCBI, Elsevier, WHO, and other health journals. The analytical method used is the systematic literature review that identifies, studies, evaluates, and develops systematically existing research with a specific focus on appropriate topics. The results of the analysis from literature sources show that vitamin $C$ has the potential of positive effects for COPD patients.
\end{abstract}

Keywords: COPD; prevention; vitamin c

\section{PENDAHULUAN}

Penyakit Paru Obstruktif Kronik (PPOK) adalah penyakit yang umum terjadi, dapat dicegah, dan dapat diobati yang ditandai dengan gejala pernapasan persisten dan keterbatasan aliran udara karena abnormalitas saluran udara atau alveolar yang biasanya disebabkan oleh 
paparan gas atau partikel berbahaya dan dipengaruhi oleh faktor penderita misalnya perkembangan paru yang abnormal (Global Initiative for Chronic Obstructive Lung Disease, 2020).

Estimasi pasien PPOK pada tahun 2015 diperkirakan mencapai 7,3 juta jiwa. Hal ini diperkirakan berkaitan dengan faktor usia tua dan kebiasaan merokok yang akan semakin meningkat (LõpezCampos, Tan, \& Soriano, 2016). Sepanjang kehidupannya, pasien PPOK dapat mengalami eksaserbasi yang sering mengganggu fungsi paru-paru dan kualitas hidup serta memperburuk prognosis sehingga meningkatkan biaya pengobatan yang dibutuhkan (Alameda, Carlos Matiá, \& Casado, 2016). Selama hidupnya, sebagian besar pasien PPOK mengalami keterbatasan dalam beraktivitas sehari-hari dan hilangnya produktivitas kerja sehingga pasien PPOK memerlukan manajemen yang dapat mencegah penurunan kualitas hidup pasien PPOK (Lim et al., 2015).

Penyakit ini merupakan penyebab kematian terbanyak keempat di seluruh dunia berdasarkan Global Burden Disease tahun 2013. Situasi ini diperkirakan terus memburuk pada beberapa tahun mendatang (Alameda et al., 2016). Selain itu, PPOK menyebabkan 3 juta kematian di dunia setiap tahunnya (Rabe \& Watz, 2017). Jumlah kematian pasien PPOK terus mengalami peningkatan. Hal ini berkaitan dengan kebiasaan merokok yang semakin tinggi (Wen et al., 2019).

Keadaan PPOK berkaitan dengan terjadinya emfisema dan remodeling saluran napas sebagai akibat dari interaksi sistem inflamasi dan imunologi yang mengakibatkan perubahan pada paru-paru (Berg \& Wright, 2016). Pasien PPOK mengalami inflamasi yang akan menghasilkan oksidan yang dapat merusak jaringan. Kerusakan tersebut juga terjadi pada molekul penting seperti antiprotease. Kerusakan antiprotease di dalam sel akan meningkatkan kerentanan terhadap kematian dan perkembangan sel alveolar emfisema (Khan, Fell, \& James, 2014). Emfisema juga terjadi karena pasien PPOK mengalami peningkatan aktivitas elastase yang berlebihan, stres oksidatif, apoptosis, dan autoimunitas (Cantor \& Turino, 2019).

Eksaserbasi akut pada PPOK merupakan penyebab pasien masuk ke rumah sakit untuk dirawat inap dan dapat menyebabkan kematian pada pasien PPOK. Penelitian oleh Flattet (2017) menyimpulkan bahwa pasien PPOK memiliki prognosis yang tidak menyenangkan, terutama setelah eksaserbasi yang membutuhkan rawat inap. Fungsi paru prediktor terkuat dari risiko mortalitas yang dialami oleh pasien PPOK. Faktor demografis, seperti usia dan penyakit penyerta, terutama diabetes dan kanker, berhubungan erat dengan hasil akhir pasien (Flattet et al., 2017).

Selain itu, status nutrisi juga merupakan faktor yang berkaitan dengan kondisi pasien PPOK (Schols et al., 2014). Berdasarkan GOLD (2020), faktor risiko PPOK adalah status sosioekonomi yang salah satunya adalah rendahnya asupan nutrisi (Global Initiative for Chronic Obstructive Lung Disease, 2020). Penelitian oleh Schols (2014) menyimpulkan bahwa diet yang seimbang bermanfaat untuk pasien PPOK karena pasien khususnya bermanfaat untuk menjaga fungsi paru (Schols et al., 2014). Sebagian besar pasien PPOK mengalami malnutrisi. 
Pada tubuh pasien PPOK terjadi defisiensi makronutrien dan mikronutrien yang dapat meningkatkan keparahan PPOK, sehingga diperlukan pencapaian status gizi yang optimal pada pasien PPOK yang bertujuan untuk menunda perkembangan penyakit. Asupan nutrisi harus dimulai sejak awal penyakit, selain itu diperlukan juga studi lebih lanjut untuk menyelidiki suplemen nutrisi yang optimal untuk pasien PPOK, sesuai dengan tingkat keparahan penyakitnya(Grigorakos, 2018).

Malnutrisi pada pasien PPOK dapat menyebabkan fungsi paru yang lebih buruk dan peningkatan risiko eksaserbasi. Pemberian suplementasi nutrisi merupakan intervensi terapeutik yang penting, terutama untuk pasien PPOK dengan malnutrisi. Suplementasi yang diberikan pada pasien PPOK bertujuan untuk meningkatkan fungsi paru-paru yang akan meningkatkan pula respon ventilasi tubuh (Hsieh, Yang, \& Tsai, 2016).

Patofisiologi PPOK berkaitan dengan terdapatnya stres oksidatif yang berperan memiliki efek langsung pada paru-paru dan jaringan tubuh lainnya, seperti otot rangka dan hati. (Collins, Yang, Chang, \& Vaughan, 2019). Penelitian di Korea oleh Hong (2018) menyimpulkan bahwa vitamin mengandung antioksidan yang memiliki manfaat terhadap fungsi paru dimana terdapat hubungan yang kuat antara konsumsi vitamin antioksidan dengan penurunan risiko terjadinya $\mathrm{PPOK}$ pada pasien (Hong, Lee, Lee, \& Kim, 2018). Beberapa nutrisi mampu mengerahkan anti-inflamasi yang kuat dan efek antioksidan adalah vitamin $\mathrm{A}, \mathrm{C}$ dan $\mathrm{E}$ (Collins et al., 2019). Vitamin C memiliki potensi untuk menghasilkan efek positif pada tubuh pasien PPOK
(Mosallanezhad, Jalali, Eftekhari, \& Ahmadi, 2019). Vitamin tersebut juga cenderung menjadi pelindung untuk menunda perkembangan PPOK (Collins et al., 2019).

Kondisi yang dialami pasien PPOK dapat menurunkan kualitas hidup serta meningkatkan risiko kematian karena mengalami PPOK eksaserbasi akut. Oleh karena itu, penelitian tinjauan literature ini penting dengan tujuan untuk mengetahui pencegahan yang dapat dilakukan terhadap pasien PPOK, salah satunya dengan memperhatikan faktor status nutrisi melalui potensi vitamin $\mathrm{C}$ dalam pencegahan PPOK. Artikel ini diharapkan dapat bermanfaat dalam menurunkan angka morbiditas ataupun mortilitas karena PPOK.

\section{METODE}

Penelitian ini berjenis tinjauan literatur atau literature review yang disusun menggunakan data sekunder berupa sumber yang diperoleh berdasarkan daftar pustaka yang tertera. Sumber pustaka yang digunakan yaitu berasal dari jurnal berupa artikel penelitian, guideline, ataupun buku elektronik seperti dari NCBI, Elsevier, WHO, dan jurnal kesehatan lainnya sebanyak 28 sumber. Kata kunci yang digunakan antara lain PPOK, vitamin C, dan pencegahan. Metode analisis yang digunakan adalah systematic literature review dengan cara mengidentifikasi, mengkaji, mengevaluasi, serta mengembangkan secara sistematis penelitian yang sudah ada dengan fokus topik tertentu yang sesuai.

\section{HASIL}

Vitamin C atau asam askorbat adalah nutrisi penting yang dibutuhkan oleh organisme multisel terutama pada manusia. Vitamin $\mathrm{C}$ merupakan vitamin yang larut dalam air (Devaki \& Raveendran, 2017). Vitamin C memiliki 
berbagai macam fungsi, salah satunya adalah perannya dalam reaksi hidroksilasi, khususnya hidroksilasi prolin dalam kolagen untuk menstabilkan struktur heliks rangkap tiga. Vitamin $\mathrm{C}$ juga berfungsi sebagai antioksidan untuk menurunkan reaksi radikal bebas sitosol (Wallig \& Keenan, 2013). Vitamin C juga mampu mengurangi gejala pada pasien PPOK secara signifikan dan meningkatkan fungsi sel imun serta menurunkan risiko infeksi saluran pernapasan yang merupakan salah satu penyebab eksaserbasi akut pada PPOK (Mosallanezhad et al., 2019).

Penelitian Park (2012) terhadap 512 pasien yang di perkirakan mengalami PPOK yang didiagnosis berdasarkan hasil pemeriksaan fungsi paru menunjukan hasil bahwa kurangnya asupan nutrisi vitamin $\mathrm{C}$ berkaitan dengan PPOK. Selain itu, terdapat penurunan risiko PPOK pada $76,7 \%$ pasien yang mengonsumsi suplementasi vitamin $C$, sehingga penelitian ini menyimpulkan bahwa mengonsumsi vitamin $\mathrm{C}$ dapat mengurangi risiko terjadinya PPOK pada pasien yang memiliki riwayat merokok (Park et al., 2016). Penelitian lainnya oleh Hartmann (2015) menggunakan ultrasound Doppler transcranial didapatkan bahwa vitamin $\mathrm{C}$ dapat meningkatkan respon ventilasi sehingga menurunkan kondisi hiperkapnia pada pasien PPOK (Hartmann et al., 2015)

\section{PEMBAHASAN}

Pada kondisi normal, epitel saluran napas terdiri dari sel-sel yang berdiferensiasi, termasuk sel-sel yang bersilia, sel yang memproduksi mukus dan sel yang memproduksi sekretoglobin (SCGB1A1), sel-sel intermediate undifferentiated, dan sel basal. Sel basal merupakan populasi sel induk yang dapat memperbaharui diri dan berdiferensiasi menjadi sel bersilia dan sel sekretori. Selain itu, reseptor yang sel basal, seperti reseptor Epidermal Growth Factor (EGF) dan Transforming Growth Factor B1 (TGFB1) akan mengirimkan sinyal untuk menghasilkan faktor pertumbuhan seperti Vascular Endothelial Growth Factor (VEGF). Selain itu, junctional barrier yang ketat berada diantara sel epitel dan berperan dalam menjaga agar saluran napas terhindar dari mikroba dan molekul beracun lainnya. Merokok menyebabkan hyperplasia sel basal, metaplasia sel-sel skuamosa, pemendekan silia, hilangnya sel yang memproduksi SCGB1A dan SCGB1A1, hiperplasia sel yang memproduksi mukus, hilangnya, perubahan epitel, fibrosis saluran napas, dan angiogenesis. Sel basal saluran napas dan memacu kerja TGF-B1 (Shaykhiev \& Crystal, 2014).

Dispnea merupakan gejala tersering yang dialami oleh pasien PPOK dengan karakteristik yang berbeda-beda. Gejala dispnea yang dialami dapat terjadi pada waktu malam atau dini hari. Variasi dispnea pada setiap individu tersebut membuat manajemen yang beragam berdasarkan sifat gejala dispnea pada pasien PPOK (O'Donnell, Milne, James, de Torres, \& Neder, 2020).

Gejala dispnea yang mengganggu sering kali dipicu oleh batuk terusmenerus dan kesulitan untuk mengeluarkan dahak. Dispnea juga berkaitan dengan aktivitas fisik dan ditandai dengan kelelahan pasien sepanjang hari yang meningkat secara bertahap (O’Donnell et al., 2020).

Batuk kronik merupakan gejala yang sering terjadi pada pasien PPOK. Gejala ini cukup dominan dialami oleh pasien 
PPOK dan merupakan fenotipe untuk mengelompokan pasien PPOK yang beresiko tinggi mengalami eksaserbasi akut. Hal tersebut dikarenakan batuk kronik berkaitan dengan rendahnya FEV1 dan DLCO (Diffusing capacity of the lungs for carbon monoxide). Batuk kronik juga berkaitan dengan risiko terjadinya dispnea yang parah dan memperburuk kualitas hidup pasien PPOK (Koo et al., 2018).

Selain itu, produksi sputum kronik juga merupakan fenotipe penting pada pasien PPOK sebagai penanda risiko eksaserbasi (Martin \& Burgel, 2019). Pada sebagian besar kultur sputum pasien yang mengalami PPOK eksaserbasi akut didapatkan bakteri. Penelitian oleh Babu (2017) didapatkan bakteri pada hasil kultur sputum pasien eksaserbasi akut yaitu sebesar $42.77 \%$, dimana $77.78 \%$ merupakan gram negative dan $22.22 \%$ merupakan gram positif. Pada penelitian tersebut juga disebutkan terdapat bakteri Klebsiella pneumoniae (27.29\%), Pseudomonas aeruginosa (24.68), dan Acinetobacter (11.69\%) (Babu, Abraham, Raj, Majeed, \& Banu, 2017).

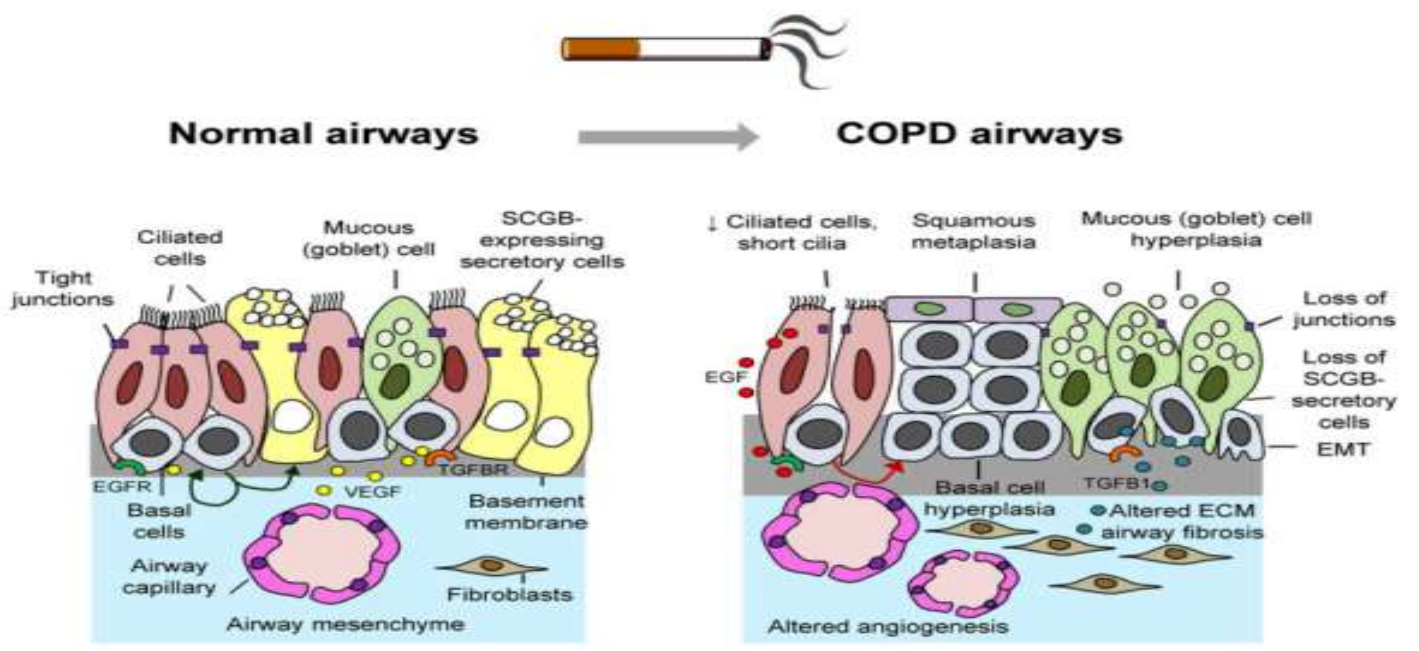

Gambar 2. Perubahan epitel jalan napas akibat merokok pada penyakit PPOK(Shaykhiev \& Crystal, 2014)

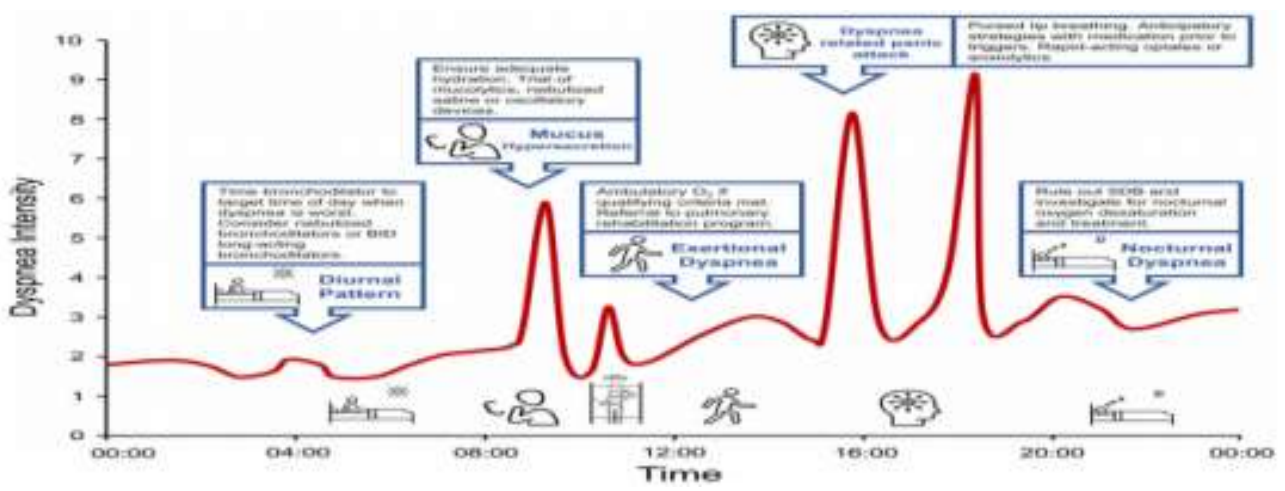

Gambar 1. Variasi Gejala Dispnea(O’Donnell et al., 2020) 
Vitamin $\mathrm{C}$ berperan penting dalam banyak proses fisiologis pada manusia untuk perbaikan jaringan di seluruh bagian tubuh. Fungsi penting vitamin $\mathrm{C}$ meliputi pembentukan protein yang digunakan untuk membuat kulit, tendon, ligamen, dan pembuluh darah untuk penyembuhan luka dan pembentukan jaringan parut. Vitamin $\mathrm{C}$ juga berperan dalam memperbaiki dan memelihara tulang rawan, tulang, dan gigi serta membantu penyerapan zat besi. Penelitian eksperimetal terhadap tikus yang diinduksi hingga mengalami emfisema menunjukkan bahwa pemberian vitamin $\mathrm{C}$ akan menyebabkan pemulihan paru. Hal ini karena pemberian vitamin $\mathrm{C}$ dapat mengurangi stres oksidatif, meningkatkan sintesis kolagen, dan meningkatkan kadar faktor pertumbuhan endotel vaskular di paruparu (Koike et al., 2014).

Vitamin $\mathrm{C}$ dapat melindungi tubuh dari pengaruh radikal bebas yang merusak karena vitamin $\mathrm{C}$ merupakan antioksidan yang dapat menetralkan radikal bebas dengan menyumbangkan salah satu elektronnya sehingga mengakhiri reaksi electron yang tidak memiliki pasangan sehingga menjadi senyawa yang stabil. Mekanisme inilah yang menjadi dasar bahwa vitamin $\mathrm{C}$ mencegah kerusakan sel dan jaringan yang dapat menimbulkan penyakit (Devaki \& Raveendran, 2017).

Vitamin $\mathrm{C}$ memegang peranan penting dalam mengatur fungsi paru melalui mengatur produksi kolagen. Vitamin $\mathrm{C}$ merupakan kofaktor lisil dan prolyl- hidroksilase yang berfungsi dalam menstabilkan struktur dan distribusi kolagen dalam tubuh. Sehingga suplementasi vitamin C akan memodulasi sintesis kolagen dan meningkatkan fungsi paru-paru berupa rasio FEV1, FVC, dan FEV1/FVC yang merupakan indeks penting dalam menilai fungsi paru-paru. (Mosallanezhad et al., 2019).

Vitamin C tidak disintesis secara endogen pada manusia, sehingga manusia sepenuhnya bergantung pada sumber makanan untuk memperoleh vitamin $\mathrm{C}$ sebagai nutrisi di dalam tubuh. Vitamin $\mathrm{C}$ hadir dalam susu dan beberapa produk hewani seperti hati dan ikan, serta berjumlah melimpah dalam berbagai buah dan sayuran (Wallig \& Keenan, 2013).

Sumber alami vitamin C dari buah didapatkan yaitu gooseberry India; buah jeruk seperti limau, jeruk dan lemon; tomat; kentang; papaya; paprika hijau dan merah; kiwi; stroberi; dan melon. Sementara vitamin $\mathrm{C}$ dari sayuran berasal dari sayuran berdaun hijau seperti brokoli (Devaki \& Raveendran, 2017).

Vitamin C dicerna di sepanjang usus kecil manusia. Vitamin $\mathrm{C}$ yang masuk ke dalam tubuh akan diserap di seluruh permukaan epitel usus. Penyerapan ini dilakukan secara difusi terfasilitasi melalui transporter GLUT1 atau GLUT3. Setelah berada di dalam sel, vitamin $\mathrm{C}$ akan diangkut di pembuluh darah oleh GLUT1 dan GLUT2 (Lykkesfeldt \& Tveden-Nyborg, 2019). 


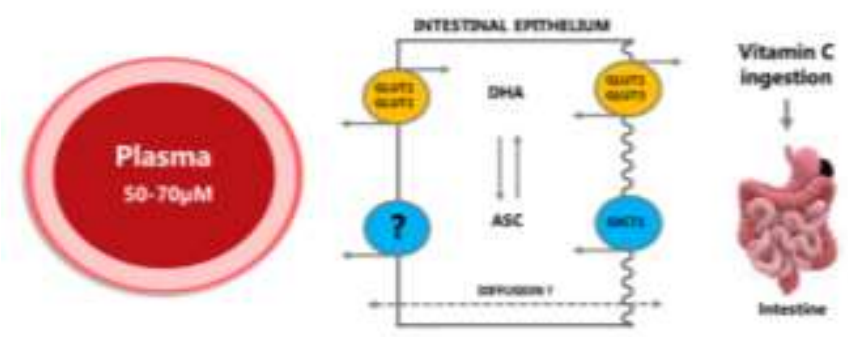

Gambar 3. Absorbsi Vitamin C dalam tubuh (Lykkesfeldt \& Tveden-Nyborg, 2019)

Selanjutnya vitamin $\mathrm{C}$ distribusikan ke organ-organ tubuh seperti otak, paru, jantung, otot, usus, ginjal, kelenjar adrenal, dan hepar (Lykkesfeldt \& Tveden-Nyborg, 2019). Efisiensi penyerapan vitamin $\mathrm{C}$ sangat tergantung pada jumlah yang dicerna, dan dapat sangat bervariasi. Pada dosis rendah (20 $\mathrm{mg}$ ), penyerapan bisa mencapai hampir $100 \%$, sedangkan pada yang lebih tinggi dosis (12 g), hanya $16 \%$ yang diserap. Pada dosis $100 \mathrm{mg} / \mathrm{hari}$ saturasi jaringan dapat tercapai.

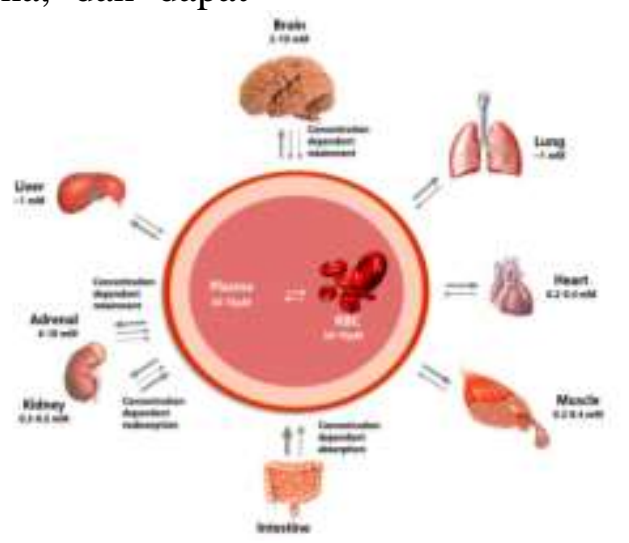

Gambar 4. Distribusi Vitamin C dalam tubuh (Lykkesfeldt \& Tveden-Nyborg, 2019)

Asupan vitamin $\mathrm{C}$ yang lebih tinggi atau lebih dari $500 \mathrm{mg} /$ hari diperlukan untuk mencapai saturasi plasma dan perlindungan maksimal sebagai antioksidan. Tetapi, dosis vitamin $\mathrm{C}$ lebih dari $1000 \mathrm{mg} / \mathrm{hari}$ dapat menyebabkan gangguan gastrointestinal, mual, dan diare osmotik, karena tubuh berusaha untuk melepaskan diri dari intraluminal yang tinggi (Koike et al., 2014).

Vitamin $\mathrm{C}$ yang dikonsumsi dalam dosis tinggi umumnya tidak menimbulkan toksisitas. Dosis maksimal vitamin $\mathrm{C}$ pada manusia bahkan mencapai 1 gram/hari. Tetapi vitamin $\mathrm{C}$ memiliki sifat yang berbeda dengan vitamin larut lemak, yaitu vitamin $\mathrm{C}$ yang larut air tidak akan terakumulasi dalam jaringan sehingga vitamin $\mathrm{C}$ dalam plasma akan mengalami filtrasi dan selanjutnya diekskresikan dalam urin. Sehingga toksisistas yang terjadi sangat minimal dan apabila terjadi toksisitas hanya berlangsung dalam waktu singkat. Toksisitas vitamin $\mathrm{C}$ yang mungkin terjadi dan harus diwaspadai adalah peningkatan ekskresi asam oksalat ke dalam urin yang dapat mengendap sebagai urolit oksalat atau urolitiasis yang mungkin terjadi karena mengonsumsi 1-2 gram/hari selama 
berbulan-bulan (Wallig \& Keenan, 2013). Penelitian lainnya menyebutkan bahwa konsumsi Vitamin C harian 2000 mg atau lebih dapat menyebabkan iritasi lambung dan usus serta batu ginjal, dan dapat mengganggu metabolisme tembaga (Salwen, 2017)

\section{SIMPULAN}

Pemberian vitamin $\mathrm{C}$ pada pasien PPOK memiliki potensi untuk menghasilkan efek positif pada tubuh pasien. Hal ini karena fungsi vitamin $\mathrm{C}$ sebagai antioksidan untuk menurunkan reaksi radikal bebas sehingga mampu mengurangi gejala pada pasien PPOK secara signifikan dan meningkatkan fungsi sel imun serta menurunkan risiko infeksi saluran pernapasan yang merupakan salah satu penyebab eksaserbasi akut pada PPOK.

\section{DAFTAR PUSTAKA}

Alameda, C., Carlos Matiá, Á., \& Casado, V. (2016). Predictors for mortality due to acute exacerbation of COPD in primary care: Protocol for the derivation of a clinical prediction rule. npj Primary Care Respiratory Medicine, 26(April), 2-4.

https://doi.org/10.1038/npjpcrm.20 16.70

Babu, D., Abraham, L., Raj, B. C., Majeed, H. P., \& Banu, S. C. (2017). Sputum Bacteriology in Patients having Acute Exacerbation of Chronic Obstructive Pulmonary Disease in a Tertiary Care Hospital. International Journal of Medical Research \& Health Sciences, 6(9), 1-5. Diambil dari www.ijmrhs.com

Berg, K., \& Wright, J. L. (2016). The pathology of chronic obstructive pulmonary disease: Progress in the 20th and 21st centuries. Archives of Pathology and Laboratory Medicine, 140(12), 1423-1428. https://doi.org/10.5858/arpa.20150455-RS

Cantor, J. O., \& Turino, G. M. (2019). COPD Pathogenesis: Finding the Common in the Complex. Chest, 155(2), 266-271. https://doi.org/10.1016/j.chest.201 8.07.030

Collins, P. F., Yang, I. A., Chang, Y. C., \& Vaughan, A. (2019). Nutritional support in chronic obstructive pulmonary disease (COPD): An evidence update. Journal of Thoracic Disease, 11(Suppl 17), S2230-S2237. https://doi.org/10.21037/jtd.2019.1 0.41

Devaki, S. J., \& Raveendran, R. L. (2017). Vitamin C: Sources, Functions, Sensing and Analysis. Vitamin $\quad C, \quad 3-20$. https://doi.org/10.5772/intechopen. 70162

Flattet, Y., Garin, N., Serratrice, J., Perrier, A., Stirnemann, J., \& Carballo, S. (2017). Determining prognosis in acute exacerbation of COPD. International Journal of COPD, 12, 467-475. https://doi.org/10.2147/COPD.S12 2382

Global Initiative for Chronic Obstructive Lung Disease. (2020). Pocket guide to COPD diagnosis, management, and prevention: a guide for health care professionals, 2020 report. GOLD.

Grigorakos, L. (2018). The role of nutrition in patients with chronic obstructive pulmonary disease. Acta Scientific Nutritional Health, 
2(4), 20-23.

Hartmann, S. E., Kissel, C. K., Szabo, L., Walker, B. L., Leigh, R., Anderson, T. J., \& Poulin, M. J. (2015). Increased ventilatory response to carbon dioxide in COPD patients following Vitamin C administration. ERJ Open Research, 1(1), 1-9. https://doi.org/10.1183/23120541.0 0017-2015

Hong, J. Y., Lee, C. Y., Lee, M. G., \& Kim, Y. S. (2018). Effects of dietary antioxidant vitamins on lung functions according to gender and smoking status in Korea: A population-based cross-sectional study. BMJ Open, 8(4), 1-9. https://doi.org/10.1136/bmjopen2017-020656

Hsieh, M. J., Yang, T. M., \& Tsai, Y. H. (2016). Nutritional supplementation in patients with chronic obstructive pulmonary disease. Journal of the Formosan Medical Association, 115(8), 595601.

https://doi.org/10.1016/j.jfma.2015 .10 .008

Khan, S., Fell, P., \& James, P. (2014). Smoking-related chronic obstructive pulmonary disease ( COPD ). Diversity and Equality in Health and Care, 11, 267-271.

Koike, K., Ishigami, A., Sato, Y., Hirai, T., Yuan, Y., Kobayashi, E., ... Seyama, K. (2014). Vitamin C prevents cigarette smoke-induced pulmonary emphysema in mice and provides pulmonary restoration. American Journal of Respiratory Cell and Molecular Biology, 50(2), 347-357. https://doi.org/10.1165/rcmb.201301210C
Koo, H. K., Park, S. W., Park, J. W., Choi, H. S., Kim, T. H., Yoon, H. K., ... Kim, D. K. (2018). Chronic cough as a novel phenotype of chronic obstructive pulmonary disease. International Journal of COPD, 13, 1793-1801. https://doi.org/10.2147/COPD.S15 3821

Lim, S., Lam, D. C. L., Muttalif, A. R., Yunus, F., Wongtim, S., Lan, L. T. T., ... De Guia, T. (2015). Impact of chronic obstructive pulmonary disease (COPD) in the Asia-Pacific region: The EPIC Asia populationbased survey. Asia Pacific Family Medicine, 14(1), 1-11. https://doi.org/10.1186/s12930015-0020-9

Lõpez-Campos, J. L., Tan, W., \& Soriano, J. B. (2016). Global burden of COPD. Respirology, 21(1), 14-23. https://doi.org/10.1111/resp.12660

Lykkesfeldt, J., \& Tveden-Nyborg, P. (2019). The pharmacokinetics of vitamin C. Nutrients, 11(10). https://doi.org/10.3390/nu1110241 2

Martin, C., \& Burgel, P. R. (2019). Do Cough and Sputum Production Predict COPD Exacerbations?: The Evidence Is Growing. Chest, 156(4), 641-642. https://doi.org/10.1016/j.chest.201 9.06.023

Mosallanezhad, Z., Jalali, M., Eftekhari, M. H., \& Ahmadi, A. (2019). The Effects of Vitamin C in Patients with Chronic Obstructive Pulmonary Disease : A Systematic Review of Clinical Trials. International Journal of Nutrition Sciences, 4(December), 170-174. 
O’Donnell, D. E., Milne, K. M., James, M. D., de Torres, J. P., \& Neder, J. A. (2020). Dyspnea in COPD: New Mechanistic Insights and Management Implications. Advances in Therapy, 37(1), 4160. https://doi.org/10.1007/s12325019-01128-9

Park, H. J., Byun, M. K., Kim, H. J., Kim, J. Y., Kim, Y. Il, Yoo, K. H., ... Ahn, C. M. (2016). Dietary vitamin $\mathrm{C}$ intake protects against COPD: The Korea National Health and Nutrition Examination Survey in 2012. International Journal of COPD, 11(1), 2721-2728. https://doi.org/10.2147/COPD.S11 9448

Rabe, K. F., \& Watz, H. (2017). Chronic obstructive pulmonary disease. The Lancet, 389(10082), 1931-1940.

https://doi.org/10.1016/S01406736(17)31222-9

Salwen, M. J. (2017). Vitamins and Trace Elements. In Henry's Clinical Diagnosis and Management by Laboratory Methods (Twenty Thi). https://doi.org/10.1016/B978-0323-29568-0.00026-7

Schols, A. M., Ferreira, I. M., Franssen, F. M., Gosker, H. R., Janssens, W., Muscaritoli, M., ... Singh, S. J. (2014). Nutritional assessment and therapy in COPD: A European respiratory society statement. European Respiratory Journal, 44(6), 1504-1520. https://doi.org/10.1183/09031936.0 0070914

Shaykhiev, R., \& Crystal, R. G. (2014). Early events in the pathogenesis of chronic obstructive pulmonary disease: $\quad$ Smoking-induced reprogramming of airway epithelial basal progenitor cells. Annals of the American Thoracic Society, 11(December), S252S258.

https://doi.org/10.1513/AnnalsATS .201402-049AW

Wallig, M. A., \& Keenan, K. P. (2013). Nutritional Toxicologic Pathology. In Haschek and Rousseaux's Handbook of Toxicologic Pathology (Third Edit). https://doi.org/10.1016/B978-0-12415759-0.00036-4

Wen, H., Xie, C., Wang, L., Wang, F., Wang, Y., Liu, X., \& Yu, C. (2019). Difference in long-term trends in COPD mortality between China and the U.S., 1992-2017: An age-period-cohort analysis. International Journal of Environmental Research and Public Health, 16(9). https://doi.org/10.3390/ijerph1609 1529 